\title{
How to Maintain a Minority Language through Education
}

\author{
Tingting Fang \\ Shanghai Maritime University, Shanghai, China \\ Email: 1508291243@qq.com
}

How to cite this paper: Fang, T. T. (2017) How to Maintain a Minority Language through Education. Chinese Studies, 6, 111.

https://doi.org/10.4236/chnstd.2017.61001

Received: January 16, 2017

Accepted: February 14, 2017

Published: February 17, 2017

Copyright $\odot 2017$ by author and Scientific Research Publishing Inc. This work is licensed under the Creative Commons Attribution International License (CC BY 4.0).

http://creativecommons.org/licenses/by/4.0/

\begin{abstract}
This paper analyses the importance of protecting minor languages, and the problems minor languages face during China's social transition. It gives suggestions and strategies on protecting the minor languages, such as carrying out the policy of bilingual education; what the family can do for it and what the school can do to protect the minority language.
\end{abstract}

\section{Keywords}

Minority Language, Education, Bilingual Education, Protecting

\section{Introduction}

\subsection{Necessity and Importance of Minority Language Maintenance}

Gao Hongna in her paper analyzes the importance of protecting minority languages, and the problems minor languages face during China's social transition. She states that language is an important component of identity and culture for many groups. Maintaining their distinct identity and culture is usually important to minority group member's self esteem and this will affect the degree of success achieved in the society. Without active language maintenance, language shift is almost inevitable in many contexts, and without conscious maintenance, minority languages can and probably will disappear in as few as three generations. Nothing benefits a country more than to treasure the language and cultures of its various peoples because in doing so, it fosters intergroup understanding and realizes greater dividends in the form of originality, creativity, and versatility (Gao Hongna, 2011).

Over half the world's population is bilingual and many people are multilingual. They acquire a number of languages because they need them for different purposes in their everyday interactions. The investigation of the individual and societal phenomena of bilingual is one of the most interesting of all those areas 
of study that fall within the general area of language and society. The study of bilingual also gives us an opportunity to relate our linguistic studies to other areas in a manner that is geminately inter-disciplinary.

All the multinational and multilingual countries in the world have to face the problem of bilingualism. Bilingualism has a great and profound significance in protecting minorities' rights and maintaining minorities' cultures.

\subsection{Necessity and Importance of Minority Language Maintenance in China}

China is a multinational and multilingual country. It has an area of about 9.6 million square kilometers which comprises about 6.5 percent of the world total land area. Its population of more than one billion accounts for 23 percent of the world human population. There are 56 nationalities which use about 80 different languages in China.

In China there are 56 nationalities, which use about 80 different languages. While there are many people who speak many different languages, they will learn each other's languages. So long as minority people have a good command of their native language and Han language as well, they can break through the language barriers and enlarge the fields of study. Meanwhile, they can introduce their native legacy of excellent culture to any other nationalities and absorb the essence of other national cultures. Bilingual is favorable to communicate national feelings and strengthen national unity.

\section{How to Maintain a Minority Language}

Where language is considered an important symbol of minority group's identity, the language is likely to be maintained longer.

If families from a minority group live near each other and see each other frequently, this also helps them maintain their language. In America, Chinese people who live in the Chinatown areas of big cities are much more likely to maintain a Chinese dialect as their mother tongue through to the third generation than those who move outside the Chinatown area.

Although the pressure to shift is string, members of a minority community can take steps to protect its language. If we consider the influence of social factors such as participants and setting, for instance, in language choice, it is clear that social factors may help resist the influence of economic pressures. Where the normal family organization for an ethnic group is the extended family with grandparents and unmarried relatives living in the same house as the nuclear family, for example, there is a good reason to continue using the minority language at home. Similarly groups which discourage intermarriage, such as the Greek and the Chinese communities, contribute to language maintenance in this way. Obviously a group who manage to ensure their language is used in settings such as school or their place of worship will increase the chances of language maintenance.

Institutional support generally makes the difference between success and fail- 
ure in maintaining a minority group language. Education, law and administration, religion and the media are crucial domains from this point of view. The minority group which can mobilize these institutions to support language maintenance has some chance of succeeding. When the government of a country is committed to maintaining or reviving a language, it is possible to legislate for its use in all these domains. There are different kinds of institutional support for maintaining a minority language. Examples of this kind of support are:

1) The use of the minority language in education, e.g. bilingual education programs, using or teaching the minority language in school;

2) Support by the law and administration, e.g. the right to use the language in court, the House of Assembly, in dealing with government officials, etc.;

3) The use of the language in places of worship, e.g. TV programs, radio programs, newspapers, and magazines.

\subsection{The Support of the Language Policy}

In order to maintain the diversity of language and protect minority languages, experts suggest that everyone can learn three to five languages, but not everyone has language the proud language learning talent and learning conditions. In these discussions, language policy plays an important role. Language policy is of great importance for status and protection of minority and culture languages as well as the construction of a harmonious society and people of all nationalities (Guo Huixiang, 2013).

It's generally thought that a country should carry out a policy where all national languages are equal, and appreciate the social values of all nationalities' languages. The country should encourage and help all minority nationalities to study and develop their own languages. According to the experiences of many countries, the best way to do that ids to approve of bilingualism, not to approve of policies of language discrimination and language assimilation. In china, $\mathrm{Pu}$ tonghua (or Mandarin) has been promoted by the Chinese government as the standard variety of Chinese since 1949 when the people's republic of china was established. Meanwhile, as a national language policy, all nationalities have had the freedom to use and develop their own spoken and written languages. In fact our country promotes and protects bilingualism by law. Upholding the policy of equality in language is of great importance to nationality relationships. China has been paying close heed to the issues regarding the freedom of all nationalities to use and develop their own languages. In China, there exists bilingualism (the Han language and a certain kind of minority language) as for the language policy of our country, it is useful to remember the points in constitution promulgated in 1982, Article 4 stipulates “all nationalities in the People's Republic of China are equal. The state protects the interests of the minority nationalities and upholds a relationship of equality, unity and mutual assistance among all nationalities. Discrimination against and oppression of any nationality are prohibited. The state assists minority people in accelerating their economic and cultural development according to their needs". It also stipulates "all nationalities have the 
freedom to use and develop their own spoken and written languages and to preserve or reform their own customs". From this article, we can realize that all nationalities have the freedom of using and developing their own languages and writing systems including the Han nationality and any minority nationalities.

Article 19 in constitution stipulates "the state promotes the nationwide use of Putonghua" Putonghua refers to the common speech. In this article, Putonghua is regarded as a standard language while minority languages are regarded as local varieties. In china Putonghua is the upper language which has been used in administration, education, and mass media. What our country popularizes is the standard language of the Han nationality in order to shape the high unity of our national languages. As far as the minority nationalities are concerned, the relationship between minority language and the Han language (Putonghua) is one between mother tongue and second language. On the one hand, our government guarantees the minority people's right to use and develop their own languages; on the other hand, minority people are encouraged to use Putonghua when they speak the Han language. And it is requires to teach Putonghua in minority nationality schools.

Article 10 in the law on regional national autonomy states "the organs of self government of national autonomous areas shall guarantee the freedom of the nationalities in these areas to use and develop their own spoken and written languages and their freedom to preserve or reform their own customs" in the law article 36, 37 and 49 also express our national language policies. Article 36 states "the organs of national autonomous areas shall decide on plans for the development of education, on the establishment of various kinds of schools and different levels, and on their educational system, forms, curricula, the language used in instruction and enrollment procedures". Article 37 states "school where most of the students come from minority nationalities should use textbooks in their own languages and use these languages as the media of instruction". Article 49 states "the organs of self government of national autonomous areas should encourage cadres of the various nationalities to learn each other's spoken and written languages."

The law on compulsory education has also made stipulations concerning language use in schools: article 6 states "schools shall promote the use of Putonghua, which is in common use throughout the nation. Schools in which the majority of students are of minority nationalities may choose minority language teaching". Article 12 in the education law stipulates "the spoken and written Chinese language shall be the basic language in teaching in schools and other institutions of education. In schools in which students of a minority ethnic group constitute the majority, language used by the ethnic group may be used for instruction". The education law is the basic law governing china's educational legislation, which confirms the Han language as a national communicative language between nationalities and confirms the Han language as an elementary one in teaching, but not the only one. There has been enough room for various teaching languages in schools and other educational institutions with minority 
nationality students.

It is necessary and important to grasp completely the stipulations in Article 4 and 19 in the constitution, and stipulations in the law on the regional national autonomy, the law on compulsory education law of our country. If we just pay attention to minorities' freedom of using and developing their own languages without considering the difference of all national languages' social functions, it will result in self closure and hinder national development. If we just put emphasis on the social function of the Han language or Putonghua without considering the irreplaceable functions of the minority languages, it will result in Han chauvinism and hinder national development.

National equality and language equality are the aims of all language policies of our country. Minority people should grasp the Han language while learning and using their mother tongues. They are encouraged to learn a foreign language for their own development and prosperity. If minority people have learned their own language and the Han as well, they may introduce their legacy of excellent culture to other nationalities and meanwhile absorb the essence of other national cultures. It is just a normal requirement for people to be bilinguals.

\subsection{Education's Effect in Maintaining Minority Language}

Education is one of the tools of language planning. Bilingual education is concerned with the use of two or more languages as mediums of instruction. There are different types of educational policies. Joshua Fishman, a renowned American socialist, has identified three models: enrichment bilingual education, transitional bilingual education and language maintenance bilingual education.

Wang Lu \& You Jing found that in order to improve ethnic minority students' academic achievements and adaptability to British society, minority language policy in Britain has always focused on improving students' English ability. The changes from taking English as a foreign language (EFL) to English as a second language (ESL) and then to English as an additional language (EAL) reflect the changes in attitude towards and educational concepts about ethnic immigrants. In the new century, based on emphasis of national identity and common values, Britain has enhanced English teaching for ethnic students through measures of making related standards, increasing capital investment and attaching importance to individual coaching, which is of inspiration to minority language education policy in China (You Jing \& Wang Lu, 2014).

\subsubsection{The Importance of the Bicultural}

Biculturalism has the ideal of equal, harmonious, mutually tolerant existence of different and diverse languages, and of religious, cultural and ethnic groups in a pluralist society. Two languages and two cultures enable a person to have dual or multiple perspectives on society. Those who speak more than one language and own more than one culture are more sensitive and sympathetic, more likely to build bridges than barricades and boundaries. Pluralism and biculturalism may lead to a positive attitude, not only to the host and heritage culture, bit to equal validity of all cultures. 


\subsubsection{The Education's Effect in Bicultural}

The impulse behind bicultural education is very largely a positive one. There are two important points, which should be considered. The first is the implication that schools possess power for social change which history shows to be rare. Schools acting in relative isolation from other social currents and the imparting of bicultural awareness and its ramifications are, unfortunately, often largely seen as educational matters which can proceed independently, have a very limited potency. The realization of this is important for all those who wish schools to act agents of change. Schools can, through their example and practice, legitimize cultural varieties and markers at least in the eyes of their possessors, but educational legitimization is not empowerment. It may lead to it, or contribute to it but, again, when schools are asked to shoulder the load almost unassisted.

The other point is that the vagueness the language may well reflect the disembodied nature of the bicultural program under consideration. There may be few who would deny the psychological and social benefits potentially associated with a heightened cultural awareness, but in order for this matter quality to be realized a minimum requirement, a necessary condition is that the bicultural thrust should be firmly embedded within an appropriate, valued and systematic context. We may draw a conclusion from the above there is a close relationship between cultural respect, which should presumably be a central feature and product of bicultural education-and value judgment. Schools also serve to further language learning as a function of boundary maintenance in maintaining elite or social status. Maintenance of a language or, more correctly, attempts at maintenance of a language through national educational policy, and also be enforced on an ethnic group from the outside, by the dominant group.

\subsubsection{Education in Bilingual Societies}

There are two important contextual aspects in the development of the education of linguistic minority children: a) they usually come from a devalued linguistic background, and b) because they often come from socially deprived socially deprived communities, their literacy oriented skills are less well developed than those of the dominant language children. They suffer from a double handicap when they are taught with children of the majority language: they have to develop literacy skills in language that they don't know or know only superficially and can't fall back on their first language (subtractive bilingualism). The poor academic achievements of these children are then attributed by society to a cognitive deficit resulting from their bilingual state. Cummins gives an excellent critical review of the use made of academic assessment tests to "demonstrate" the bilingual deficit of minority schoolchildren. He shows that there is strong experimental evidence that highly valuing the first culture of minority children and introducing literacy skills in the children's first language enhance both linguistic and academic achievement. So even if bilingual education appears to be a necessary condition for the maintenance of minority culture and language, it is not a sufficient one. Only a strong ethno linguistic vitality, the use of the mother tongue in the home and in the speech community, and allegiance to the cultural 
group will ensure cultural and linguistic survival.

\subsubsection{School Education's Effect in Language Maintenance}

School is traditionally a strong arm of culture, and central to its aims has always been a strong emphasis upon language. The control of language use has in most cases one of two objectives: language maintenance or language shift.

Ethnic group members usually hold the concern about mother-tongue maintenance and the too rapid shift to the other tongue. Ethnic groups may wish to use language for purposes other than an appreciation of their cultural heritage. Mother-tongue maintenance is an efficient means of maintaining ethnic boundaries. School also serve to further language learning as a function of boundary maintenance in maintaining elite or social status. There can't be only one way to improve the teaching efficiency, the teaching method should put into the specific subject's settlement, while the subject needs a good teaching materials to support. How a subject and textbook could be is determined by different factors, and it should be settled together with the headmaster and teachers. And if it get the support and help from many people who have participated in a few language projects, then the whole process could be accelerated.

Ha Zhengli\& Yang Jiaqi said that under the background of modernization and globalization, the protection of the ethnic minorities' language has become a complicated social work (Yang Jiaqi \& Ha Zhengli, 2012). They point out some current situations as well as proposed some suggestions for protecting and developing ethnic minorities' languages. There are several methods to motivate students' positivity, while there are five principles need to be emphasized, in different language teaching, the point of emphasize is different: 1 the communication is more important than grammar; 2 the real context should be used; 3 the teaching content should focus on the theme that learners interested in; 4 during the study of the learners, the guidance should be constantly adjusted, the teaching content could be from simple to difficult.

Maintenance of a language or, more correctly, attempts at maintenance of a language through national educational policy may also be enforced on an ethnic group from the outside, by the dominant group. So, the education to the minority language needs a set of complete plan, and get a large scale of group's support including local schools.

\subsubsection{The Importance of Family's Education}

As some scholars said: "in fact, the rights of the language use can't ensure the survival of the language, it ultimately depends on the mother tongue's user's decision. It definitely confuses the institution, because it beyond their control." Though it is said that the establishment of a school or declarement of some language as an official language is easier than to let the family members talk with their kids in their own minority language, however, only in the way of latter, can the minority language be heritage, which indicates that the official language policy didn't exert so important influence in the family. Therefore, in any case, if we make the language survive in the daily life, these official measures are not 
enough.

Tian Youlan \& Zhou Xiaomei in their articles argues that language policy, school and family are of the same importance for protection and renewing endangered minority languages. They give some suggestions about family education on minority languages (Tian Youlan \& Zhou Xiaomei, 2013).

Brandt, E. A., \& Ayoungman, V. proposed a suggestion in Canadian Journal of Native Education that the family members should talk with their kids in the simple words rather than to teach the national language just through fragmentary vocabularies like foods, colors or numbers (Brandt \& Ayoungman, 1989). They should carry out some practical talk with kids, such as put up questions to them and tell them how to say the their own language in practical scene. Besides, the learning and teaching minority language indeed need the elder's help, while the younger parents' creation of the family's environment is also of critical importance. Whether it is in the school or being out, the minority students need the corresponding language environment, the family is undoubtedly one of the places using minority language (Tian Youlan \& Zhou Xiaomei, 2013).

\section{Bilingual Education's Effect in Maintaining Minority Language}

An Mei in her article emphasized the importance of the bilingual education, she said that the bilingual education has been very profound in maintaining and developing a national language, and further strengthening its group identity and cultural structure. Bilingual education is also regarded as a means of minority language support. Effective bilingual schooling has generally involved a process known as "immersion". Children are immersed in the language, and it is used to teach them science, mathematics and social studies, for instance, they are not "taught" the language. It is rather used as a medium of instruction to teach them the normal school curriculum. This method has proved very successful in many different countries as a means of learning a second language (An Mei, 2011).

When a language is rated as high in status by its users, and yet also regarded as a language of solidarity to be used between minority group members, where it is regarded as appropriate for expressing referential as well as affective or social meaning, and where it is also to be used in a wide range of contexts both formal and informal, it is much more likely to be maintained. There is clearly no magic formula for guaranteeing language maintenance or for predicting language shift or death. Different factors combine in different ways in each social context, and the results are rarely predicable. Similar factors apparently result in stable bilingual situation in some communities but language shift in others. This account has stressed importance of economic, social, demographic and attitudinal factors. Economic factors are very influential and rarely work in favor of maintaining small minority group languages. Successful resistance requires a conscious and determined effort to maintain the minority language.

Though economic and political imperatives tend to eliminate minority languages, it is important to remember examples like welsh which demonstrate that 
languages can be maintained, and even revived, when a group values their distinct identity highly and regards language as an important symbol of that identity. Finally, it is also important to realize that pressures towards language shift occur mainly in countries where monolingual is regarded as normal, and bilingualism is considered unusual. For most of the world it is bilingualism and multilingualism which is normal.

Therefore, it seems to be extremely urgent and necessary to protect the minority language and culture.

Bilingual education is considered one of the most important measures taken to maintain languages and cultures. Bilingual education of the Han and minority language has developed a lot. The Yandong primary school in Liping County was taken as an example to illustrate it. There are two classes (Class one and Class two) with 89 students in grade 4. At the end of 1984, all students took part in the final examination. The average grade of the Chinese test of class one is 43.7 , with a $15.2 \%$ rate of pass, and the average grade of class two is 54.5 , with a $42.9 \%$ rate of pass. The grade of class two is 10.8 higher than that of class one. All students of class one, with an exception of one Chinese student who can speak the Dong language, are Dong nationality pupils. The school carried out experimental bilingual education in class one. Teachers are required to add 6 lessons of the Dong language each week in addition to the existing 26 lessons. And in the final examination of that semester, all students of class one passed the Dong language test and pupils got 8 pupils got 100. The average Chinese mark of this class is 63.3 , and this grade is 5.3 higher than that of class two. From this experimental class, we learn that these bilingual pupils can get good performance both in the Han language and Dong language. Obviously, it will not influence the study of Chinese but improve their proficiency in learning for students to master the Dong language.

However, there still exist some problems in bilingual education in the Han and Dong language. For example:

1) We should consider bilingual education from the point of view of the constitution. The lawful position of minority nationality languages cannot be ignored. The idea that minority nationality languages are used as transitional languages has never been based any laws.

2) We must understand bilingual education from the point of view of inheriting and developing national culture. The profound significance of bilingual education in maintaining and developing national culture cannot be underestimated.

3) We need more administrative support for bilingual programs in school. Teachers need to be competent bilinguals, with high levels of Han and native-language proficiency. So they can respond to pupils' needs.

The education is an important way to acquire various advanced knowledge and techno ledge so that realize the nation's development; meanwhile, it's also an indispensible tool to maintain nation's cultural heritage. The education includes school's education, family's education and social education these three 
types. Actually, in most nations only having language but without characters, the nation's traditional culture were maintained by family's education and social education. In modern school's education, the bilingual education is the main channel for minority language entering into the class.

Therefore, whether we use the tool of carrying out the policy to maintain the minority language or take humanistic care to the disadvantaged groups, the bilingual education is still the important way to realize the maintenance of multi-languages (Wu Zhengbiao, 2010).

As we know that language policy, school and family are of the same importance for protection and renewing endangered minority languages, so is early children endangered minority language education.

Though it is impossible just relying on the school to realize the language's maintenance and revival, the school is an important part among them. Because of the systematic teaching, the appropriate ways and the regular study could strengthen the use of the minority language. In addition, if the school takes the minority language as a subject, the minority language will be taken seriously like other subjects.

\section{Conclusion}

As we have explained in the paper, there are many factors which could contribute to language maintenance such as the patterns of language use, demographic factors, institutional support, attitudes towards majority and minority, and government policies towards language and education of minorities. Different cultures have different ideas about the integrity of their own group in relation to outsiders. If speakers of the minority language manage to find an ecological niche in the majority community which is conductive to language maintenance, they may have a better chance of survival. Given the fact that bilingualism is a world phenomenon, and given also that official and prestige status is often restricted, it is apparent that attitudes towards bilingualism and language diversity in general are important.

China is a typical multinational and multilingual country; therefore, it is a normal part of human existence to understand a second language or language variety. Policies of language planning and language reform have been carried out successfully. The strength of the Han language as a second language among nationality is derived not only from the institutional pressures supporting the Han language, but also the pressures to develop some medium of communication between groups with different mother tongues. The dominant status of Putonghua as a national common speech has been further strengthened.

Chinese constitution and laws have given all the minority nationalities the freedom of using and developing their own languages. According to Chinese language policies towards minority nationalities, the country should help minority nationalities to create and reform scripts. It suggests that our country has been paying a close attention to the use and development of minority nationality languages in addition to advocating all nationalities to learn and use Putonghua 
as a common speech.

Education is one of the tools of language planning. Even if bilingual education appears to be a necessary condition for the maintenance of minority culture and language, it is not the sufficient one. Only a strong ethno linguistic vitality, the use of the mother tongue in the home and in the speech community, and allegiance to the culture group will ensure linguistic survival.

The years after World War II have seen the reappraisal or official language policy in many countries, where the state apparatus tries to maintain some of the minority languages, both indigenous and foreign. In any case, without deeper knowledge of a community's language values, or at least better survey data, it is impossible to say whether language maintenance or language shift is to be expected in the future. Without active language maintenance, shift is inevitable in many contexts, and without conscious maintenance, minority language can and probably will disappear in as far as three generations. Therefore, nothing benefits a country more than treasure the languages and cultures of its various peoples.

\section{References}

An Mei. 安梅. (2011). Protection of Minority Langauge under Bilingul Environment 双 语环境下的少数民族语言维护. Guizhou Ethnic Studies 贵州民族研究, 185-190.

Brandt, E. A., \& Ayoungman, V. (1989). Language Renewal and Language Maintenance: A Practical Guide. Canadian Journal of Native Education, 16, 42-77.

Gao Hongna. 高红娜. (2015). On the Protection and Development of the Minor Languages during China's Social Transition 论社会转型期少数民族语言的保护与发展. Guizhou Ethnic Studies 贵州民族研究, 198-201.

Guo Huixiang. 郭慧乡. (2013). Research on Language Polocy and Minority Education's Fairness 语言政策与少数民族教育公平性研究. Guizhou Ethnic Studies 贵州民族研 究, 170-173.

Tian Youlan, \& Zhou Xiomei. 田有兰, 周晓梅. (2013). An Abroad Research on the Education of Endangered Minority Languages 国外少数民族濒临语言教育研究. Guizhou Ethnic Studies 贵州民族研究, 197-200.

Wu Zhengbiao. 吴正彪. (2010). On Important Role of Bilingual Education in Inheritance and Protection of Intangible Cultural Heritage of Ethnic Minorities 论双语教育在传 承与保护少数民族非物质文化遗产中的重要作用. Journal of Research on Education for Ethnic Minorities, 21, 107-111.

Yang Jiaqi, \& Ha Zhengli. 杨佳琦, 哈正利. (2012). Experience and Enlightenment from the Protection of Overseas Ethnic Minorities' Languages 国外少数民族语言保护经验 及其启示. Guangxi Ethnic Studies 广西民族研究, 189-193.

You Jing, \& Wang Lu. 尤静, 王璐. (2014). A Study on Evolution of Minority Language Education Policyand Its Latest Development in Britain 英国少数民族语言教育政策 理念演进及最新进展探析. Journal of Research on Education for Ethnic Minorities, 25, 73B-78B. 
Submit or recommend next manuscript to SCIRP and we will provide best service for you:

Accepting pre-submission inquiries through Email, Facebook, LinkedIn, Twitter, etc. A wide selection of journals (inclusive of 9 subjects, more than 200 journals)

Providing 24-hour high-quality service

User-friendly online submission system

Fair and swift peer-review system

Efficient typesetting and proofreading procedure

Display of the result of downloads and visits, as well as the number of cited articles Maximum dissemination of your research work

Submit your manuscript at: http://papersubmission.scirp.org/

Or contact chnstd@scirp.org 